DOI: 10.17707/AgricultForest.63.3.03

\begin{abstract}
Abdulvahed KHALEDI DARVISHAN, Morteza BEHZADFAR, Velibor SPALEVIC, Patrick KALONDE, Abdessalam OUALLALI, Sabri el MOUATASSIME ${ }^{1}$
\end{abstract}

\title{
CALCULATION OF SEDIMENT YIELD IN THE S2-1 WATERSHED OF THE SHIRINDAREH RIVER BASIN, IRAN
}

\section{SUMMARY}

Soil erosion by water as a natural process can occur in all climates and zones and change all landforms. As the measuring of soil erosion is costly and time consuming process, dozens of erosion prediction models have been developed and the aim of the majority of all of them is to predict average rates (often an annual average rate) of soil loss from an area such as a plot, a field or a catchment/watershed under various land management techniques. On the other hand, outflow is the most important element of the hydrological cycle and that is why it is important to determine it as accurately as possible by measuring and predicting. Therefore, the IntErO (Intensity of Erossion and Outflow) model based on the EPM (Erosion Potential Method) method was used for calculation of outflow and sediment yield in the S2-1 watershed of Shirindareh River Basin in the Northeast Iran with the area of $46.77 \mathrm{~km} 2$. According to the results, the predicted peak discharge was $101 \mathrm{~m} 3 \mathrm{~s}-1$ for the incidence of 100 years and the specific sediment yield was $267 \mathrm{~m} 3 \mathrm{~km}-2$ year- 1 . According to the previous studies and topographic characteristics, the river basin watershed belongs to the $\mathrm{V}$ category and has very weak erosion. The results of the present study and previous experiences of the other researchers revealed that the IntErO model can be used to estimate soil loss in the other regions similar to Shirindareh River Basin.

Keywords: IntErO, Runoff, Specific sediment yield, Shirindareh Watershed, Soil erosion

\section{INTRODUCTION}

Watersheds are in fact often affected by natural disasters, above all floods, overflows, inundations, erosion problems, landslides and pollution (Tazioli et al.

\footnotetext{
${ }^{1}$ Abdulvahed Khaledi Darvishan (corresponding author: a. khaledi@modares.ac.ir), Department of Watershed Management Engineering, Faculty of Natural Resources, Tarbiat Modares University, Noor, IRAN, Morteza Behzadfar, Faculty of Natural Resources, Tarbiat Modares University, Noor, IRAN, Velibor Spalevic Department of Geography, Faculty of Philosophy, University of Montenegro, Niksic, MONTENEGRO, Patrick Kalonde Environmental Science and Management Department, Lilongwe University of Agriculture and Natural Resources, Faculty of Natural Resources, Lilongwe, MALAWI, Abdessalam Ouallali Department of geology, Abdelmalek Essaadi University, Faculty of Science, Tetouan, MOROCCO, Sabri el Mouatassime Faculty of Technical Sciences, University Soltane Moulay Slimane, Béni Mellal, MOROCCO.

Presented at the 7th International Symposium of Ecologists (ISEM7), Sutomore, Montenegro.

Notes: The authors declare that they have no conflicts of interest. Authorship Form signed online.
} 
2015). There are several stages/types of water erosion, including splash, sheet, interrill, rill, gully and stream bank erosion (Khaledi Darvishan et al. 2012; Khaledi Darvishan et al. 2014 and 2015, Gholami et al. 2016). Soil erosion and sediment yield studies are therefore of great interest in Asia (especially in arid and semi-arid regions), because of their effects on soil thickness and fertility, plant cover, runoff coefficient and flood risk. The widespread environmental impacts of soil erosion and loss are often not enough faced by the governments (Behzadfar et al. 2014). The problem of soil loss and land degradation, with their huge impact on the environment is a key point for agriculture, ecology, hydrology and hydrogeology studies.

Knowing or estimating the accurate quantity of soil erosion in a watershed is therefore essential and one of the basic steps of all studies to encompass lots of environmental problems and to evaluate the amount of sediment moved, transported and deposited in and out of the basin. On the other hand, direct measurements of erosion in a watershed are possible with multi-years measurement of solid transport in the closing-section (Tazioli, 2009).

The suspended load can be measured through different techniques (Edwards and Glysson 1999; IAEA; 2005), for instance tracing techniques, nuclear probes, optical and acoustic probes, digital imaging analysis and direct sampling (IAEA, 2005).

Sediment load measurements are useful to calibrate soil erosion models (Tazioli et al. 2005; Khaledi Darvishan et al. 2010; Tazioli, 2009; Spalevic, 2011; Sadeghi et al. 2013, 2014). Modelling, in fact, is a good, often necessary and proven tool useful to evaluate the amount of discharge and erosion in a watershed, especially when hydrometric and discharge data are not available (Behzadfar et al. 2014). Mathematical erosion models were therefore developed to predict soil erosion and sediment yield in a sub-catchment area, based on simple mathematical equations such as Universal Soil Loss Equation (USLE), or based on some modified and updated versions (Wischmeier and Smith, 1965, 1978).

Evaluation of the applicability of soil erosion models to a watershed is not easy, as it is difficult to accurately measure soil erosion in the field (Conoscenti et al. 2008, Rawat et al. 2011). In contrast, sediment yield models are easier to apply, because the data for these models can be measured at the watershed outlet (Kinnell and Riss 1998; Erskine et al. 2002; Kinnell, 2010).

Among several models, Erosion Potential Method - EPM, originally developed for Yugoslavia by Gavrilovic (1972), was in recent times repeatedly applied in the watersheds of Apennine and in the Balkan Peninsula (Blinkov and Kostadinov, 2010; Kostadinov et al. 2006, 2014; Lenaerts, 2014; Milevski et al. 2008; Ristic et al. 2012; Sekularac, 2000, 2013; Spalevic et al. 2012a, 2012b, 2013a, 2013b, 2013c, 2013d, 2013e, 2013f, 2013g, 2014a, 2014b, 2014c, 2014d, 2014e, 2014f; Stefanovic, 2004; Tazioli, 2009, Zorn and Komac, 2008), but also in the other regions in the world, for example in arid and semi-arid areas of the south-western USA (Gavrilovic Z., 1988). The method is based on the factors affecting erosion in a catchment; its parameters dependent on the temperature, 
the mean annual rainfall, the soil use, the geological properties and some other features of the catchment.

The Intensity of Erosion and Outflow - IntErO program package (Spalevic, 2011), developed to predict the intensity of soil erosion and the runoff peak discharge in a watershed, is a computer-graphic method based on the Erosion Potential Method - EPM, which is embedded in its algorithm.

In the present research, the IntErO model was verified and tested in a small sub-catchment of Shirindareh watershed in Iran, which is one of the main tributaries of the River Atrak.

\section{Study area}

\section{MATERIAL AND METHODS}

The present study was conducted in a small sub-catchment of Shirindareh watershed in north eastern part of Iran, which is mountainous, with the presence of deep incised valleys (in Limestone Mountains) but also hilly. Rivers in this region drain to the Caspian Sea (Behzadfar et al. 2014).

Shirindareh is one of the main tributaries of the river Atrak. Atrak originates from Hezar-Masjed Mountains in the region of Razavi Khorasan and lies between steep slopes and plains till to enter the territory of Turkmenistan on Chaat region and finally drain to Caspian Sea in the Gulf of Hasan Ghuly. Shirindareh river basin area has the important strategic values for North Khorasan province (Behzadfar et al. 2014; Gholami et al. 2016). A rock fill dam has been constructed on the main river of the basin, because of need to supply of drinking water and agriculture. So, the management of upland areas is very important to increase performance of the dam.

The studied sub-catchment (S2-1) encompasses an area of $46.77 \mathrm{~km} 2$ and is categorized in the group of the small watersheds of the natural entity of the Shirindareh river basin (Figure 1).

The average slope gradient in the river basin, Isr, is calculated on $28.46 \%$, indicating that in the river basin prevail steep slopes. The average river basin altitude (Hsr), the average elevation difference of the river basin (D), the natural length of the main watercourse $(\mathrm{Lv})$ and the shortest distance between the fountainhead and the mouth (Lm) are $1912.59 \mathrm{~m}, 441.59 \mathrm{~m}, 12.87 \mathrm{~km}, 10.59 \mathrm{~km}$, respectively which were calculated by the IntErO program package (source: original).

\section{Fieldwork \& laboratory analysis}

During the field work, using a morphometric methods, various data on intensity and forms of soil erosion, land use, and the measures taken to reduce or mitigate erosion were recorded. Different forms including the shape of the slope, the depth of the erosion base and the density of erosion rills were determined.

Pedological survey was based on the research of the National Geological Survey Organization (NGS) led by Bolourchi et al. (1987), who analyzed the physical and chemical properties of all geological formations of North Khorasan province, including those in the study area of the Shirindareh Basin and all it's sub-catchments. 


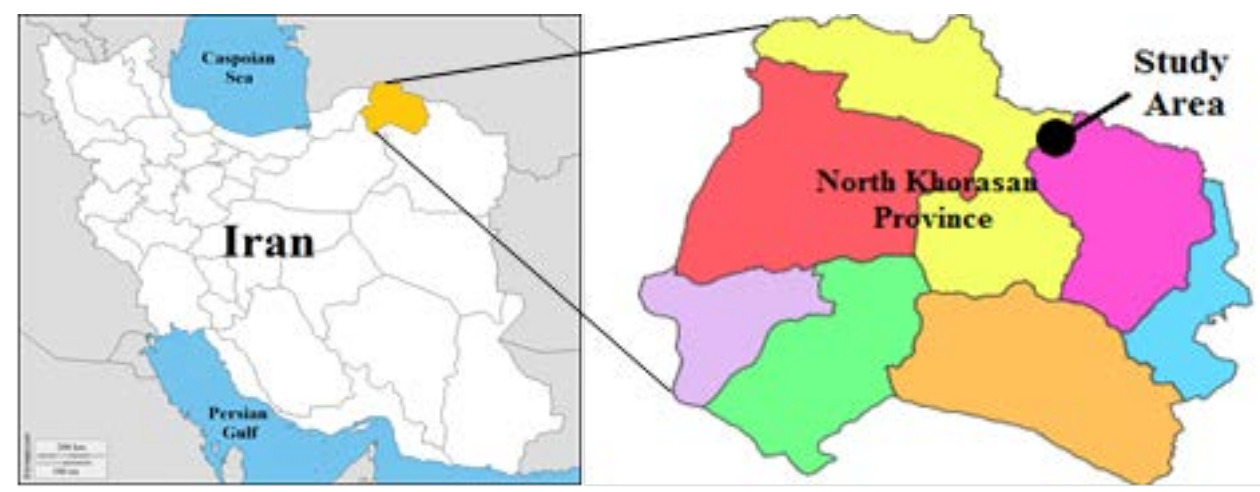

Figure 1. The location of the study area

\section{IntERO model application}

The Intensity of Erosion and Outflow - IntErO program package (Spalevic, 2011) was used to estimate maximum runoff discharge from the basin and the intensity of soil erosion, with the Erosion Potential Method - EPM (Gavrilovic, 1972) embedded in the algorithm of this computer-graphic method.

The above methodology was used in Bosnia \& Herzegovina, Bulgaria, Croatia, Czech Republic, Italy, Iran, Montenegro, Macedonia, Serbia and Slovenia (Kostadinov et al. 2014). In Iran, the IntERO have been successfully used previously in the Regions of Chamgardalan; Kasilian (Amiri, 2010; Zia Abadi \& Ahmadi, 2011; Yousefi et al. 2014) and some other sub-catchments of Shirindareh River basin (Behzadfar et al. 2014 and 2015; Barovic et al. 2015; Gholami et al. 2016).

\section{Climatic characteristics}

\section{RESULTS}

The climate of the study area is a continental climate with cold winters and warm and dry summers. The absolute maximum air temperature is $34.6^{\circ} \mathrm{C}$ and the negative temperatures can fall to a minimum of $-24.4^{\circ} \mathrm{C}$. The average annual air temperature (t0) and the average annual precipitation (Hyear) are $8.7^{\circ} \mathrm{C}$ and $352 \mathrm{~mm}$, respectively, based on the data from the North Khorasan meteorological stations of Iran. The temperature coefficient of the region $(\mathrm{T})$ and the amount of torrential rain (hb) were calculated equal to 0.98 and $37.57 \mathrm{~mm}$ respectively.

\section{The geological structure and soil characteristics of the area}

To calculate some inputs of IntERO, the geological data was extracting from the geological map of Iran (Bolourchi et al. 1987). The geological data showed that the structure of the river basin, according to bedrock permeability, is the following: poor water permeability rocks (f0), medium permeable rocks (fpp) and very permeable products from rocks (fp) were $37 \%, 48 \%$ and $15 \%$, respectively. The coefficient of the region's permeability, S1, was calculated about 0.77 (source: original). The most common soil type in the studied area is Inceptisols with Calcic horizon. 


\section{Vegetation and land use}

The studied area is located in Middle-East of the Kope-Dagh geographical region. According to the analysis, the main portion of the river basin is totally under mountain pastures (55.78\%). The coefficient of the river basin planning, (Xa) and the coefficient of the vegetation cover (S2) were calculated about 0.64 and 0.77 , respectively.

Part of the detailed report for the S2-1 watershed is shown in Table 1

Table 1. Part of the IntErO report (inputs and outputs) for the S2-1 watershed

\begin{tabular}{|c|c|c|c|}
\hline \multicolumn{4}{|l|}{ INPUTS } \\
\hline River basin area & $\mathrm{F}$ & 46.77 & $\mathrm{~km}^{2}$ \\
\hline The length of the watershed & $\mathrm{O}$ & 36.33 & $\mathrm{~km}$ \\
\hline Natural length of the main watercourse & Lv & 12.87 & $\mathrm{~km}$ \\
\hline The shortest distance between the fountainhead and mouth & $\mathrm{Lm}$ & 10.59 & $\mathrm{~km}$ \\
\hline $\begin{array}{l}\text { The total length of the main watercourse with tributaries of I and II } \\
\text { class }\end{array}$ & $\Sigma \mathrm{L}$ & 71.79 & $\mathrm{~km}$ \\
\hline River basin length measured by a series of parallel lines & Lb & 12.18 & $\mathrm{~km}$ \\
\hline The area of the bigger river basin part & Fv & 31.84 & $\mathrm{~km}^{2}$ \\
\hline The area of the smaller river basin part & Fm & 14.94 & $\mathrm{~km}^{2}$ \\
\hline Altitude of the first contour line & h0 & 1500 & $\mathrm{~m}$ \\
\hline The lowest river basin elevation & Hmin & 1471 & $\mathrm{~m}$ \\
\hline The highest river basin elevation & Hmax & 2514 & $\mathrm{~m}$ \\
\hline A part of the river basin consisted of a very permeable products from rocks & $\mathrm{fp}$ & 0.15 & \\
\hline A part of the river basin area consisted of medium permeable rocks & fpp & 0.48 & \\
\hline A part of the river basin consisted of poor water permeability rocks & fo & 0.37 & \\
\hline A part of the river basin under the forests & fs & 0.30 & \\
\hline A part of the river basin under grass, meadows, pastures and orchards & $\mathrm{ft}$ & 0.56 & \\
\hline A part of the river basin under plough-land and without vegetation & fg & 0.14 & \\
\hline The volume of the torrent rain & $\mathrm{hb}$ & 37.57 & $\mathrm{~mm}$ \\
\hline Average annual air temperature & t0 & 8.70 & ${ }^{\circ} \mathrm{C}$ \\
\hline Average annual precipitation & Hyr & 352 & $\mathrm{~mm}$ \\
\hline Types of soil products and related types & $\mathrm{Y}$ & 1.10 & \\
\hline River basin planning, coefficient of the river basin planning & Ха & 0.64 & \\
\hline Numeral equivalents of visible and clearly exposed erosion process & $\varphi$ & 0.57 & \\
\hline \multicolumn{4}{|l|}{ OUTPUTS } \\
\hline Coefficient of the river basin form & A & 0.55 & \\
\hline Coefficient of the watershed development & $\mathrm{m}$ & 0.56 & \\
\hline Average river basin width & B & 3.84 & $\mathrm{~km}$ \\
\hline (A)symmetry of the river basin & $\mathrm{a}$ & 0.72 & \\
\hline Density of the river network of the basin & $\mathrm{G}$ & 1.53 & \\
\hline Coefficient of the river basin tortuousness & $\mathrm{K}$ & 1.22 & \\
\hline Average river basin altitude & Hsr & 1912.59 & $\mathrm{~m}$ \\
\hline Average elevation difference of the river basin & $\mathrm{D}$ & 441.59 & $\mathrm{~m}$ \\
\hline
\end{tabular}




\begin{tabular}{|l|c|c|c|}
\hline Average river basin decline & Isr & 28.46 & $\%$ \\
\hline The height of the local erosion base of the river basin & Hleb & 1043.00 & $\mathrm{~m}$ \\
\hline Coefficient of the erosion energy of the river basin's relief & $\mathrm{Er}$ & 126.95 & \\
\hline Coefficient of the region's permeability & $\mathrm{S} 1$ & 0.77 & \\
\hline Coefficient of the vegetation cover & $\mathrm{S} 2$ & 0.77 & \\
\hline Analytical presentation of the water retention in inflow & $\mathrm{W}$ & 0.4921 & $\mathrm{~m}$ \\
\hline Energetic potential of water flow during torrent rains & $2 \mathrm{gDF} \wedge 1 / 2$ & 636.56 & $\mathrm{~m} \mathrm{~km} \mathrm{~s}$ \\
\hline Maximal outflow from the river basin & $\mathrm{Qmax}$ & 101.32 & $\mathrm{~m}^{3} / \mathrm{s}$ \\
\hline Temperature coefficient of the region & $\mathrm{T}$ & 0.98 & \\
\hline Coefficient of the river basin erosion & $\mathrm{Z}$ & 0.789 & \\
\hline Production of erosion material in the river basin & $\mathrm{Wyr}$ & 35667.74 & $\mathrm{~m}^{3} / \mathrm{yr}$ \\
\hline Coefficient of the deposit retention & $\mathrm{Ru}$ & 0.350 & \\
\hline Real soil losses & $\mathrm{Gyr}$ & 12493.38 & $\mathrm{~m}^{3} / \mathrm{yr}$ \\
\hline Real soil losses per $\mathrm{km}^{2}$ & $\mathrm{Gyr} / \mathrm{km}^{2}$ & 267.12 & $\mathrm{~m}^{3} / \mathrm{km}^{2} \mathrm{yr}$ \\
\hline
\end{tabular}

\section{DISCUSSION}

According to the results, surface erosion has taken place in all the soils on the slopes as the dominant erosion form in the studied area which is the most pronounced on the steep slopes with scarce vegetation cover.

The coefficient of the river basin form, A, calculated as 0.55 using IntErO software. Coefficient of the watershed development, $\mathrm{m}$, was 0.53 and the average river basin width, B, was $3.84 \mathrm{~km}$. (A)symmetry of the river basin, a, which indicates that there is a possibility for large flood waves to appear in the river basin, was calculated as 0.72 .

Drainage density, G, was calculated as $1.53 \mathrm{~km} \mathrm{~km}-2$ which corresponds to high density of the hydrographic network. The height of the local erosion base of the river basin, Hleb, was $1043 \mathrm{~m}$ and also the coefficient of the erosion energy of the river basin's relief, Er, was calculated as 126.95.

The value of $\mathrm{Z}$ coefficient as 0.789 indicates that the river basin belongs to II destruction category. The strength of the erosion process is high, and according to the erosion type, it is surface erosion, the second destruction category out of five.

For the current state of land use, calculated peak flow is $101.32 \mathrm{~m} 3 \mathrm{~s}-1$ for a return period of 100 years.

The production of sediments in the basin, Wyear, is calculated as 35667.7419 m3year-1; and the Coefficient of the intra-basin deposition, $\mathrm{Ru}$, at 0.350 which indicates that $35 \%$ of the eroded materials will deposit and remain in the watershed.

Sediment yield at catchment outlet (Gyear) was calculated as 12493.38 m3year-1; and specific sediment yield at $267.12 \mathrm{~m} 3 \mathrm{~km}-2$ year-1.

The study was conducted in the area of the S2-1 Basin of Shirindareh region, one of the main tributaries of the river Atrak in Iran. The soil erosion intensity and runoff were calculated using the IntErO model. According to the 
findings, it can be concluded that there is a possibility for large flood waves to appear in the studied S2-1 river basin.

Calculated peak flow is $101.32 \mathrm{~m} 3 \mathrm{~s}-1$ for a return period of 100 years. The value of $\mathrm{Z}$ coefficient of 0.789 indicates that the river basin belongs to the second destruction category out of five. The calculated net soil loss from the river basin was $12493 \mathrm{~m} 3$ per year, specific $267 \mathrm{~m} 3 \mathrm{~km}-2$ per year. The strength of the erosion process is strong, and according to the erosion type, it is surface erosion.

\section{CONCLUSION}

This study further confirmed the findings of Amiri (2010), Zia Abadi \& Ahmadi, (2011), Yousefi et al. (2014), Behzadfar et al. (2014 and 2015) as well as Gholami et al. (2016) in successful implementation of the Erosion Potential Method - EPM and/or IntERO model in Iran, what leads to the conclusion that the IntErO model may be a useful tool for researchers in calculation of runoff and sediment yield at the level of the river basins draining to the Caspian Sea.

\section{ACKNOWLEDGEMENTS}

Field work was carried out in 2014 and 2015, funded by the Natural Resources and Watershed Management Office, North Khorasan province of Iran. Authors would like to thank all the experts contributed in filed works.

\section{REFERENCES}

Amiri, F. (2010) Estimate of Erosion and Sedimentation in Semi-arid Basin using Empirical Models of Erosion Potential within a Geographic Information System. Air, Soil and Water Research, 3, 37-44.

Barovic, G. Leandro Naves Silva, M. Veloso Gomes Batista, P. Vujacic, D. Soares Souza, W. Cesar Avanzi, J. Behzadfar M. \& Spalevic, V. (2015) Estimation of sediment yield using the IntErO model in the S1-5 Watershed of the Shirindareh River Basin, Iran. Agriculture and Forestry, 61(3), 233-243.

Behzadfar, M. Tazioli, A. Vukelic-Shutoska, M. Simunic, I. \& Spalevic, V. (2014) Calculation of sediment yield in the S1-1 Watershed, Shirindareh Watershed, Iran. Agriculture and Forestry, 60(4), 207-216.

Behzadfar, M. Curovic, M. Simunic, I. Tanaskovik, V. \& Spalevic, V. (2015) Calculation of soil erosion intensity in the S5-2 Watershed of the Shirindareh River Basin, Iran. International Conference on Soil, Tirana, Albania; 4-7 May 2015.

Blinkov, I. \& Kostadinov, S. (2010) Applicability of various erosion risk assessment methods for engineering purposes, BALWOIS 2010 Conference - Ohrid, Republic of Macedonia. 25-29 May 2010.

Bolourchi, M. Mehr Parto, M. \& Afsharharb, A. (1987) Geological quadrangle map of Iran no. J5 (Bojnurd sheet), scale 1:250,000, Geological Survey of Iran.

Conoscenti, C. Di Maggio, C. \& Rotigliano, E. (2008) Soil erosion susceptibility assessment and validation using a geostatistical multivariate approach: a test in Southern Sicily. Natural Hazards, 46(3), 287-305.

Edwards TK. \& Glysson GD. (1999) Field methods for measurement of fluvial sediment. In: Techniques of water-resources investigation of the U.S. Geological Survey, Chap. 2, pp. 89. 
Erskine, W.D. Mahmoudzadeh, A. \& Myers, C. (2002) Land use effects on sediment yields and soil loss rates in small basins of Triassic Sandstone near Sydney, NSW, Australia. Catena, 49, 271-287.

Gavrilovic, S. (1972) Inzenjering o bujicnim tokovima i eroziji. Izgradnja. Beograd.

Gavrilović, Z. (1988) The use of empirical method (erosion potential method) for calculating sediment production and transportation in unstudied or torrential streams. In: White, W. R. (ed.), International Conference on River Regime; 411422. Chichester.

Gholami, L. Batista, P.V.G. Behzadfar, A. Khaledi Darvishan, A. \& Behzadfar, M. (2016) Application of Intero Model for Soil Loss Estimation Case Study: S7-1 Watershed of Shirindareh River Basin, Iran. Agrosym 2016, 2169-2177.

International Atomic Energy Agency (IAEA), (2005) Fluvial sediment transport: Analytical techniques for measuring sediment load. IAEA-TECDOC-1461. ISBN 92-0-107605-3.

Khaledi Darvishan, A. Banasik K. Sadeghi S.H.R. Gholami, L. \& Hejduk L. (2015) Effects of rain intensity and initial soil moisture on hydrological responsesin laboratory conditions. International Agrophisics, 29, 165-173.

Khaledi Darvishan, A. Sadeghi S.H.R. \& Gholami, L. (2010) Efficacy of Time-Area Method in Simulating Temporal Variation of Sediment Yield in Chehelgazi Watershed, Iran. Annals of Warsaw University of Life Sciences, 42(1), 51-60.

Khaledi Darvishan, A. Sadeghi, S.H.R. Homaee, M. \& Arabkhedri, M. (2012) Potential Use of Synthetic Color-Contrast Aggregates and a Digital Image Processing Technique in Soil Splash Measurements, IAHS Publication, No. 356, 364-368.

Khaledi Darvishan, A. Sadeghi, S.H.R. Homaee, M. \& Arabkhedri, M. (2014) Measuring Sheet Erosion using Synthetic Color-Contrast Aggregates. Hydrological Processes, 28(15), 4463-4471.

Kinnell, P.I.A. \& Riss, L.M. (1998) USLE-M: empirical modeling rainfall erosion through runoff and sediment concentration. Soil Science Society of America Journal, 62, 1662-1672.

Kinnell, P.I.A. (2010) Event soil loss, runoff and the Universal Soil Loss Equation family of models: a review. Journal of Hydrology, 385, 384-397.

Kostadinov, S. Zlatic, M. Dragicevic, S. Novkovic, I. Kosanin, O. Borisavljevic, A. Lakicevic, M. \& Mladjan, D. (2014) Anthropogenic influence on erosion intensity changes in the Rasina river watershed - Central Serbia. Fresenius Environmental Bulletin, 23(1a), 254-263

Kostadinov, S. Zlatic, M. Dragovic, N. \& Gavrilovic, Z. (2006) Soil Erosion in Serbia and Montenegro. In Boardman, J., Poesen, J. (eds), Soil Erosion in Europe. John Wiley \& Sons, Ltd, London, pp. 271-277.

Lenaerts, T. (2014) Geomorphological mapping of Montenegro: Landform genesis and present processes. Master thesis, University of Gent, Faculty of Geography, 128 pp.

Milevski, I. Blinkov, I. \& Trendafilov, A. (2008) Soil erosion processes and modeling in the upper Bregalnica catchment. XXIVth Conference of the Danubian Countries. On the hydrological forecasting and hydrological bases of water management, 2-4 June 2008, Bled, Slovenia. 190 pp.

Rawat, P.K. Tiwari, P.C. Pant, C.C. Sharama, A.K. \& Pant, P.D. (2011) Modelling of stream run-off and sediment output for erosion hazard assessment in Lesser Himalaya: need for sustainable land use plan using remote sensing and GIS: a case study. Natural Hazards, 59, 1277-1297. 
Ristic, R. Kostadinov, S. Abolmasov, B. Dragicevic, S. Trivan, G. Radic, B. Trifunovic, M., \& Radosavljevic, Z. (2012) Torrential floods and town and country planning in Serbia. Natural Hazards and Earth System Sciences, 12, 23-35.

Sadeghi, S.H.R. Gholami, L. \& Khaledi Darvishan, A. (2013) Suitability of MUSLT for Storm Sediment Yield Prediction in Chehelgazi Watershed, Iran. Hydrological Sciences Journal, 58(4), 892-897.

Sadeghi, S.H.R. Gholami, L. Khaledi Darvishan, A. \& Saeidi, P. (2014) A Review of the Application of the MUSLE Model World-Wide. Hydrological Sciences Journal, 59(1-2), 365-375.

Sekularac G. (2000) Odnos intenziteta erozije i stepena erodiranosti zemljišta sliva reke Kamenice. Doktorska disertacija. Agronomski fakultet, Čačak, Srbija.

Sekularac, G. Jelic, M. Kulina, M. Jakisic, T. \& Jugovic, M. (2013) Soil erosion of the Cuverak River Basin (West Serbia). IV International Symposium, Agrosym 2013, 807-810.

Spalevic, V. (2011) Impact of land use on runoff and soil erosion in Polimlje. Doctoral thesis, Faculty of Agriculture of the University of Belgrade, Serbia, 260 pp.

Spalevic, V. Curovic, M. Andjelkovic, A. Djekovic, V. \& Ilci, S. (2014a) Calculation of soil erosion intensity in the Nedakusi Watershed of the Polimlje Region, Montenegro. International Scientific conference: Challenges in modern agricultural production, December 11, 2014, Skopje, Macedonia.

Spalevic, V. Čurović, M. Borota, D. \& Fuštić, B. (2012a) Soil erosion in the river basin Zeljeznica, area of Bar, Montenegro. Agriculture and Forestry, 54(1-4), 5-24.

Spalevic, V. Curovic, M. Simunic, I. Behzadfar, M. \& Tanaskovic, V. (2014b) Land degradation, land use and soil erosion: the case of Montenegro. CIHEAM, The Watch Letter: Land Issues in the Mediterranean Countries, 28(1), 58-62.

Spalevic, V. Curovic, M. Tanaskovik, V. Oljaca, M. \& Djurovic, N. (2013a) The impact of land use on soil erosion and run-off in the Krivaja river basin in Montenegro. The First International Symposium on Agricultural Engineering, 4th - 6th October 2013, Belgrade-Zemun, Serbia, VI, 1-14.

Spalevic, V. Curovic, M. Tanaskovik, V. Pivic, R. \& Djurovic, N. (2013b) Estimation of soil erosion intensity and runoff in the river basin of Bijeli Potok, Northeast of Montenegro. In proceeding of the 1st International Congress on Soil Science, XIII Congress of Serbian Soil Science Society “SOIL - WATER - PLANT”, October, 2013. Belgrade, Serbia.

Spalevic, V. Curovic, M. Uzen, N. Simunic, I. \& Vukelic-Shutoska, M. (2013c) Calculation of soil erosion intensity and runoff in the river basin of Ljesnica, Northeast of Montenegro. In proceeding of the 24th International Scientific-Expert Conference on Agriculture and Food Industry, Sarajevo, Bosnia and Herzegovina.

Spalevic, V. Djurovic, N. Mijovic, S. Vukelic-Sutoska, M. \& Curovic, M. (2013d). Soil Erosion Intensity and Runoff on the Djuricka River Basin (North of Montenegro). Malaysian Journal of Soil Science, 17, 49-68.

Spalevic, V. Grbovic, K. Gligorevic, K. Curovic, M. \& Billi, P. (2013e) Calculation of runoff and soil erosion on the Tifran watershed, Polimlje, North-East of Montenegro. Agriculture and Forestry, 59(4), 5-17.

Spalevic, V. Hübl, J. Hasenauer, H. \& Curovic, M. (2014c) Calculation of soil erosion intensity in the Bosnjak Watershed, Polimlje River Basin, Montenegro. The 5th International Symposium “Agrosym 2014”, Jahorina, 23-26 October 2014, Bosnia and Herzegovina, 730-738.

Spalevic, V. Nyssen, J. Curovic, M. Lenaerts, T. Kerckhof, A. Annys, K. Van Den Branden, J. \& Frankl, A. (2013f) The impact of land use on soil erosion in the 
river basin Boljanska Rijeka in Montenegro. In proceeding of the 4th International Symposium, Agrosym 2013, 54-63.

Spalevic, V. Mahoney, W. Djurovic, N. Üzen, N. \& Curovic, M. (2012b). Calculation of soil erosion intensity and maximum outflow from the Rovacki river basin, Montenegro. Agriculture and Forestry, 58(3), 7-21

Spalevic, V. Radanovic, D. Behzadfar, M. Djekovic, V. Andjelkovic, A. \& Milosevic, N. (2014d) Calculation of the sediment yield of the Trebacka Rijeka, Polimlje, Montenegro. Agriculture and Forestry, 60(1), 259-272.

Spalevic, V. Railic, B. Djekovic, V. Andjelkovic, A. \& Curovic, M. (2014e) Calculation of the Soil Erosion Intensity and Runoff of the Lapnjak watershed, Polimlje, Montenegro. Agriculture and Forestry, 60(2), 261-271.

Spalevic, V. Simunic, I. Vukelic-Sutoska, M. Uzen, N. \& Curovic, M. (2013g) Prediction of the soil erosion intensity from the river basin Navotinski, Polimlje (Northeast Montenegro). Agriculture and Forestry, 59(2), 9-20.

Spalevic, V. Tazioli, A. Djekovic, V. Andjelkovic, A. \& Djurovic, N. (2014f) Assessment of soil erosion in the Lipnica Watershed, Polimlje, Montenegro. The 5th International Symposium, Agrosym 2014, 723-729.

Stefanovic, M. Gavrilovic, Z. \& Milojevic, M. (2004) Erosion Potential method and erosion risk zoning in mountainous regions. In Internatioales Symposion Iterprevent-RIVA\TRIENT.

Tazioli, A. (2009) Evaluation of erosion in equipped basins: preliminary results of a comparison between the Gavrilovic model and direct measurements of sediment transport. Environmental Geology, 56(5), 825-831.

Tazioli A. Mattioli A. Nanni T. \& Vivalda P.M. (2015) Natural hazard analysis in the Aspio equipped basin. Engineering geology for Society and Territory, 3, 431-435.

Wischmeier, W.H. \& Smith, D.D. (1965) Predicting rainfall-erosion losses from cropland east of the Rocky Mountains. Agricultural Handbook No. 282, US Department of Agriculture, Washington, DC.

Wischmeier, W.H. \& Smith, D.D. (1978) Predicting rainfall erosion losses. Agriculture Handbook, n. 537. Agriculture Research Service, US Department of Agriculture, Washington, DC.

Yousefi, S. Kivarz, N. Ramezani, B. Rasoolzadeh, N. Naderi, N. \& Mirzaee, S. (2014) An Estimation of Sediment by Using Erosion Potential Method and Geographic Information Systems in Chamgardalan Watershed: A Case Study of Ilam Province, Iran. Geodynamics Research International Bulletin, 2(2): XXXIV to XLI.

Zia Abadi, L. \& Ahmadi, H. (2011) Comparison of EPM and geomorphology methods for erosion and sediment yield assessment in Kasilian Watershed, Mazandaran Province, Iran. Desert, 16, 103-109.

Zorn, M. \& Komac, B. (2008) Response of soil erosion to land use change with particular reference to the last 200 years (Julian Alps, Western Slovenia). XXIVth Conference of the Danubian Countries. Hydrological forecasting \& hydrological bases of water management, June 2008, Bled, Slovenia. 205 pp. 